\title{
TRADITIONAL MADRASAH, STATE POLICIES AND THE RISE OF INTEGRATED ISLAMIC SCHOOLS IN JAMBI ${ }^{1}$ \\ Marwazi | UIN Sulthan Thaha Saifuddin Jambi - Indonesia \\ M. Husnul Abid | UIN Sulthan Thaha Saifuddin Jambi - Indonesia \\ Corresponding authors: marwazi@uinjambi.ac.id
}

\begin{abstract}
This paper discusses why the schools were wellliked and flourished; what factors drive this phenomenon? Different from many studies that have analyzed the development of integrated Islamic schools in general in Indonesia, this article focuses on the more specific Jambi case. Using social movement theory, this article argues that in addition to liberal policies that open wide opportunities for anyone to express themselves in the public sphere, including Islamists, the need for the Jambi Malay community for religious education is also an important factor. While previously this need was fulfilled by the presence of traditional Malay madrasas, which teach Islam in the afternoon after students return from school, the education standardization policy implemented by the Indonesian government has made their existence deteriorate. Taking advantage of these conditions, integrated Islamic schools have emerged to offer a full-day Islamic education model to the Muslim middle class, who are anxious about their children's future due to lack of supervision after their time is up for work.
\end{abstract}

Keywords: Islamic education, madrasah, policy of education.

\section{Introduction}

The tendency of educational institutions in Indonesia, especially in the last two decades, shows that they accommodate the secular school system with the Islamic teaching system in the form of madrasah and even pesantren. These educational institutions, which among others call

\footnotetext{
1 This article is primary based on a research sponsored by Lembaga Penelitian dan Pengabdian pada Masyarakat (LPPM) of UIN Sulthan Thaha Saifuddin Jambi under the project "Religion-Based Social Movement" with contract number 1017/2016. In addition to LPPM, we also thank the research team members, namely Maisah, Samsu, and Su'aidi.
} 
themselves integrated Islamic schools (sekolah Islam terpadu), are an alternative to the previous dualism of general and religious education. Using the name sekolah (school), the integrated Islamic schools try to combine the two systems but provide a sizable portion of Islamic teaching and make it a strong characteristic. ${ }^{2}$ Thriving and very popular especially in cities, the integrated Islamic schools numbered more than 2,700 units in 2017 and are members of Jaringan Sekolah Islam Terpadu (Integrated Islamic School Network, JSIT), one of the umbrella organizations that supervises these schools. ${ }^{3}$

Many scholars have provided explanations for why the new schools developed so rapidly and the factors supporting it. Their explanations generally lead to the conclusion that schools with Islamic characteristics such as integrated Islamic schools are a consequence of the development of new Islamic enthusiasm that has emerged since the 1970s. After the New Order policy at the beginning of its administration did not side with Islam, several Islamist organizations such as Dewan Dakwah Islamiyah Indonesia (Indonesian Islamic Da'wah Council, DDII) led by Mohammad Natsir established Islamic activism centered on secular campuses. The Normalisasi Kehidupan Kampus/Badan Koordinasi Kampus (Normalization Policy of Campus Life/Campus Coordinating Board, NKK/BKK) policy which excluded students from activities only on campus and away from socio-political issues, also contributed to the spread of this cultural movement so that it became popular and students affiliated with it controlled official student organizations on campus. When the New Order fell in 1998, the movement's networks among urban Muslim middle class were strongly exist. Taking advantage from the political openness era that followed, the movement known as the Tarbiyah Movement (Arabic: ḅarāka tarbiya) changed its preaching strategy from cultural to structural. Apart from creating many activities and organizations that become the center of activism for its members, ${ }^{4}$ the

\footnotetext{
2 On the dualism of Indonesian educational system, see Karel A. Steenbrink, Pesantren, Madrasah, Sekolah: Pendidikan Islam dalam Kurun Moderen (Jakarta: LP3ES, 1994).

3 Suaidi Asyari, "Incorporating Islamism into Secular Education System: An Attempt of Gradual Islamization of the State and Society by an Indonesian Tarbiyah Movement in Jambi," Journal of Indonesian Islam, 11, 1 (2017), pp. 29-58.

4 Samsu and M Husnul Abid, "Organizing People, Islamizing the Society: Organizations, Da'wah, and Ideology within the Indonesian Tarbiyah Movement", forthcoming.
} 
movement also established Partai Keadilan (Justice Party, PK) as a path of practical political struggle. ${ }^{5}$ After only gaining 1.36 percent of the vote in the first post-Reformasi election, the party which later transformed into Partai Keadilan Sejahtera (Prosperous Justice Party, PKS) became the most consistent Islamic party in obtaining votes with more than 6 percent in subsequent elections (2004, 2009, 2014, and 2019). 6 The existence of the Tarbiyah Movement in Indonesia has consequences on the needs of its members for educational institutions, which led them to establish integrated Islamic schools. The school is a place of learning for children of its members, which is useful for maintaining the continuity of the movement's ideological transmission to them, as well as for preaching their ideology to groups outside the Tarbiyah Movement. ${ }^{7}$

While previous studies on integrated Islamic schools were mostly carried out at a broad and general level in Indonesia, with the conclusions as mentioned above, this article investigates the emergence of these schools at the local level, taking a specific case of Jambi. It argues that the local context, on which this article is based, offers a more empirical perspective on the emergence and development of integrated Islamic schools in the area. The forms of educational institutions in Indonesia, especially those that serve Islamic education, however, are not single. In various regions, different Islamic educational institutions are found; it may be that one form of

\footnotetext{
5 Ali Said Damanik, Fenomena Partai Keadilan: Transformasi 20 Tabun Gerakan Tarbiyah di Indonesia (Jakarta: Teraju, 2002); M. Imdadun Rahmat, Ideologi Politik PKS: Dari Masjid Kampus ke Gedung Parlemen (Yogyakarta: LKiS, 2008); Aay Muhammad Furqon, Partai Keadilan Sejabtera: Ideologis dan Praksis Politik. Kaum Muda Muslim Indonesia Kontemporer (Jakarta: Teraju, 2004).

${ }^{6}$ Burhanuddin Muhtadi, Dilema PKS: Suara dan Syariah (Jakarta: Kepustakaan Populer Gramedia, 2012).

7 This typical analyzes are proposed by, among other, Noorhaidi Hasan, "Education, Young Islamists and Integrated Islamic Schools in Indonesia," Studia Islamika, 19, 1 (2012), pp. 77-111; Noorhaidi Hasan, "Islamizing Formal Education: Integrated Islamic School and a New Trend in Formal Education Istitution in Indonesia," RSIS Working Paper, No. 172, (Singapore: Nanyang Technological University, 2009); Karen Bryner, "Piety Projects: Islamic Schools for Indonesia's Urban Middle Class," Unpublished Ph.D thesis at Columbia University (2013); Suzaina Kadir, "Emerging Trends in Islamic Education in Indonesia", paper presented at the 3rd Redesigning Pedagogy International Conference, National Institute of Education, Singapore, 1-3 June 2009 .
} 
institution in one region is not found in another area. ${ }^{8}$ The presence of a new educational institution such as integrated Islamic schools, therefore, poses different challenges and responses in each region. It is important to consider the local context when discussing the development of integrated Islamic schools, besides a more general analysis is of course also needed.

This article is divided into several sections. Following introduction, discussion on the social movement theory used in this article is displayed. After that, the article focuses on the Jambi context as well as the province's needs for Islamic education. The next section discusses traditional Islamic educational institutions in Jambi that existed before the emergence of the integrated Islamic schools, followed by a section describing the establishment of this new Islamic education institution. Apart from the various efforts made by the Tarbiyah Movement, acceptance of an integrated Islamic school in Jambi is also due to Indonesian government policies related to (Islamic) education. This discussion is conveyed in a separate section, before the closing section which concludes the dynamics of the establishment of the integrated Islamic schools in Jambi and their acceptance by the Malay community from the perspective of social movement theory.

\section{Islamic Education Institutions and Social Movement}

In general, there are various types of Islamic education institutions in Indonesia. In its informal form, Islamic teaching is first given in pengajian al-Qur'an (Quran recitation), both in mosques between sunset and evening time or in people's homes. There, an ustädz (teacher) gives the first Islamic lessons to pre-school or elementary school children in the form of introducing Arabic letters for the benefit of reading the Qurān properly and correctly according to its rules of pronunciation (tajwid). As the most important source of Islam, the Quran is taught to Muslim children, at least how to read it, so that it will be repeated and guided for the rest of their lives.

The more formal traditional Islamic education institutions are pesantren, which have various names in various regions of Indonesia, such as dayah (Aceh), surau (West Sumatra), and madrasab (Jambi). Led by a charismatic teacher or kiai, the pesantren teaches Islamic religious subjects such as tafsir (interpretation of the Quran), Hadith, theology,

\footnotetext{
${ }^{8}$ Steenbrink, Pesantren, Madrasah, Sekolah.
} 
Sufism, and Arabic grammar which are contained in kitab kuning. ${ }^{9}$ The pesantren environment usually consists of a kyai's house, a mosque or langgar as a place of worship as well as a place of learning, and pondok where students come and leave the pesantren without being bound by the school year. ${ }^{10}$

In the mid-19th century, when the Dutch colonial government planned to build a public education system to qualify colonial officials, one of the debates that arose was whether the government should build an entirely new education system or, as was tradition in other colonies, adopt a system which already exists, namely the pesantren, to serve as a starting point. After a series of investigations, it was concluded that the didactic traditions of the traditional educational institutions were "too bad" that they could not be combined to open public education. In addition, it was feared that a very large amount would drain state finances if the previous system would be accommodated. ${ }^{11}$

Because the colonial government established a new educational institution, the pesantren then "went on their own way, apart from the government, stuck to its own traditions."12 After that, due to various factors, especially the entry of ideas for Islamic reform as a result of the encounters of students or pilgrims leaving for the Middle East and the emergence of Islamic organizations such as Muhammadiyah and Nahdlatul Ulama, the traditional educational institutions began to improve. ${ }^{13}$ Pesantren, for example, renewed itself by not only teaching religious lessons, but also adding general knowledge and accepting female students or santriwati. ${ }^{14}$ While young leaders in Minangkabau who are alumni of the Middle East introduced madrasab as an alternative to the pesantren-style education offered by traditionalist

\footnotetext{
9 Martin van Bruinessen, Kitab Kuning, Pesantren dan Tarekat: Tradisi-tradisi Islam di Indonesia (Bandung: Mizan, 1995).

10 Zamakhsyari Dhofier, Tradisi Pesantren: Studi tentang Pandangan Hidup Kyai (Jakarta: LP3ES, 1982).

${ }^{11}$ Steenbrink, Pesantren, Madrasah, Sekolah, pp. 3-7.

12 Ibid., p. 7.

13 Ibid., pp. 26-28.

14 Robert W. Hefner, "Islamic Schools, Social Movements, and Democracy in Indonesia", Robert W. Hefner (ed.), Making Modern Muslims: The Politics of Islamic Education in Southeast Asia (Honolulu: University of Hawai'i Press, 2009), pp. 62-65.
} 
groups, ${ }^{15}$ modernist organizations such as Muhammadiyah and Persatuan Islam developed religious schools that imitated colonial schools or at least replicated schools owned by their secular-nationalist counterpart, namely Budi Utomo, who founded Taman Siswa. ${ }^{16}$ These modernist religious education institutions, together with pesantren, later became known as Islamic educational systems, in opposition to general or public schools introduced by the colonial government or secularnationalist groups.

When Indonesia gained its independent in 1945, dualism or a dual system of general and religious education was maintained, especially as a solution to the conflict between secular-nationalist and religious leaders regarding the National Education System compiled by the new state. As a consequence, in subsequent periods the government was forced to seek "continually changing the design of the dual system to reduce the gap between 'public' and 'religious' schools, and gradually seek a more unified school system." 17 One of the most important was the joint decree between the Minister of Education and Culture, the Minister of Religion, and the Minister of Home Affairs in 1975 which stated that madrasab have the same status as public schools. The requirement was that madrasab change their learning content from previously focused on religious sciences to 70 percent general subjects and only 30 percent religious lessons. In 1994, the government introduced a new curriculum that made more than 80 percent of the madrasah curriculum the same as general schools and madrasah was only allowed to provide seven hours of religious instruction a week as extracurricular activities. With these various efforts and developments, Karel A. Steenbrink said that "Islamic education... gradually adapts itself and enters the general education system." 18

The majority of Islamic education institutions welcomed these unification efforts with the aim of providing wider opportunities for

15 Ibid., p. 61. See further Steenbrink, Pesantren, Madrasah, Sekolah, pp. 35-50; Taufik Abdullah, Schools and Politics: The Kaum Muda Movement in West Sumatra (1927-1933) (Ithaca: Southeast Asia Program, Cornell University, 1971); Burhanuddin Daya, Gerakan Pembabaruan Pemikiran Islam: Kasus Sumatera Thawalib (Yogyakarta: Tiara Wacana, 1990).

16 Muhammad Sirozi, Politik Kebijakan Pendidikan di Indonesia: Peran Tokoh-tokoh Islam dalam Penyusunan UU No. 2/1989 (Leiden-Jakarta: INIS, 2004), pp. 37-38; Steenbrink, Pesantren, Madrasah, Sekolah, pp. 50-58.

17 Sirozi, Politik Kebijakan Pendidikan, p. 42.

18 Steenbrink, Pesantren, Madrasah, Sekolah, p. 7. 
their alumni to get equal work options with public school alumni and their certificates could be used to apply to public universities. The period from the 1970s to the 1980s then saw the massive establishment of madrasabs within pesantren institutions. Only a few pesantren have maintained their old educational curriculum, such as Pesantren Gontor, which since its inception was more internationally oriented learning in English and Arabic, and Pesantren Lirboyo which did not provide non-religious lessons, known as salaf, as opposed to khalaf or pesantren with a mixed curriculum.

While Pesantren Gontor and Lirboyo can be categorized as moderate, recently, especially after the Reformasi, new, more conservative educational institutions have emerged. Some institutions may have been established long before, but they only showed their conservative and even radical characters after the regime change in 1998. Taking advantage of the weakness of the state due to the riots leading up to and during the political transition, some non-mainstream Islamic groups rose and gained their existence in Indonesia's public sphere. Some used violence and terror, while others struggled peacefully by adopting the means provided by the government. ${ }^{19}$ The two groups later also established educational institutions as a medium of disseminating their Islamist ideas in order to gain wider resonances and supports. In turn, in their own way, they then challenged the country. This last point raises the idea of linking Islamic educational institutions and what are known as social movements.

Often defined as "collective challenges, based on common purposes and social solidarities, in sustained interaction with elites, opponents, and authorities", social movements imply the state as the primary target of the changes that are being pursued. Although there is no reason to assume that all social movements, more specifically Islamic education, are state-oriented, their efforts are expected to exert influence on a broad scale for citizens and society and possibly on a state scale, at least the state changes for the better according to their values. Such an ideal of course belongs to all Islamic educational institutions and therefore, from a broad perspective, "Indonesia's

${ }^{19}$ Noorhaidi Hasan, Laskar Jihad: Islam, Militansi, dan Pencarian Identitas di Indonesia PascaOrde Baru, trans. by Hairus Salim, (Jakarta: LP3ES, 2008); Julie Chernov Hwang, Peaceful Islamist Mobilization in the Muslim World: What Went Right (New York: Palgrave Macmillan, 2009). 
Islamic schools bear an at least partial resemblance to the social movements." 20

Despite such intersections, however, theories in social movements can be used to examine new trends or changes in education and its institutions. The three most popular concepts of these theories, which will be applied in this article, are that the success of a social movement depends on: political opportunity structures, cycles of contention, and framing. A brief explanation of these concepts is that social movements often emerge when there are major changes in politics that provide new opportunities for actors to act. Of course, these actors do not move alone, but together with other actors create a social network that is shaped like a life cycle: planning, forming, consolidating, and leading to contention. ${ }^{21}$ In this cycle, the capabilities of actors are very important, especially in rolling out or framing issues that will ultimately be responded to by the public. ${ }^{22}$

\section{Local Needs in Religious Education}

This article argues that in addition to national-scale developments and political policies, the local context also needs to be considered in order to discuss the new institutionalization of Islamic education in Indonesia. This section provides the Jambi context on which this article was based, as well as the traditional educational institutions, prior to the arrival of integrated Islamic schools.

Jambi Province is on the island of Sumatra. Its territory extends from the low-lying east coast, often called as ilir, to the west side of the island, which is the plateau, or ulu. ${ }^{23}$ The Batanghari River, one of the longest rivers in Indonesia, along with dozens of its branches, cross parts of Jambi territory, making them important transportation routes

\footnotetext{
${ }^{20}$ Hefner, "Islamic Schools", p. 70.

21 An aspect of the social movements, according to some theorists, is protest or contention. Donatella Della Porta and Mario Diani, Social Movements: An Introduction (Madison-Oxford-Victoria: Blackwell, second edition 2006), especially chapters "Action Forms, Repertoires, and Cycle of Protest" and "The Policing of Protest and Political Opportunities for Social Movements", pp. 163-222; William A. Gamson, "Constructing Social Protest", Hank Johnston and Bert Klandermans (eds), Social Movements, Protest, and Contention, vol. 4 (Minneapolis: The University of Minnesota Press, 1995), pp. 85-105.

22 Hasan, Laskar Jihad, pp. 131-133.

23 Barbara Watson Andaya, "Upstreams and Downstreams in Early Modern Sumatra", The Historian, 53, 3 (1995), pp. 537-552.
} 
especially in the past. On the outskirts, there are many traditional Malay villages, the original and largest tribes in Jambi (see Table 1). Although later being synonymous with Islam, prior to the arrival of this religion in Jambi, the Malays in Jambi were Buddhists. One proof of the greatness of Buddhism in Jambi is the Muarajambi Temple, a complex of ancient buildings covering an area of 3,981 hectares, which is believed to be one of the most important Buddhist education centers in Southeast Asia in the 7 th to 12 th centuries. ${ }^{24}$

Table 1. Ethnic composition in Jambi, 2010

\begin{tabular}{lc}
\hline Ethnic Group & Percent \\
\hline Malay & 40.35 \\
Javanese & 29.09 \\
Kerinci & 8.67 \\
Minangkabau & 5.33 \\
Batak & 3.46 \\
Banjarese & 3.33 \\
Bugisnese & 3.13 \\
Sundanese & 2.58 \\
Palembang & 1.68 \\
Chinese & 1.21 \\
Others & 1.16 \\
\hline
\end{tabular}

Source: Aris Ananta, et.al., Demography of Indonesia's Ethnicity (Singapore: ISEAS, 2015). ${ }^{25}$

It is not known exactly when the Malays converted to Muslims. Even though in the 14th century, Islam was already strong enough on the Malay Peninsula, "most of Sumatra was not yet willing to embrace this new religion, and the Kingdom of Malayu (in western Jambi) was one of the areas that persisted in defending itself against the 'threat' of Islam." 26 To deal with Islamization, elements of Tantrism in Buddhism were developed, which in fact caused the decline of the religion in $\mathrm{Jambi}^{27}$ A century later, in the eastern area of Jambi, the Jambi sultanate was founded. The establishment of this Islamic empire on

${ }^{24}$ UNESCO, "Muarajambi Temple Compound”, https://whc.unesco.org/en/tentativelists $/ 5465 /$.

25 Aris Ananta, et.al., Demography of Indonesia's Ethnicity (Singapura: ISEAS, 2015), p. 105.

${ }^{26}$ Uli Kozok, Kitab Undang-undang Tanjung Tanab: Naskab Melayu yang Tertua (Jakarta: Yayasan Obor Indonesia, 2006), p. 17.

27 Ibid., p. 17. 
the one hand, and the decline of Buddhism on the other, made the spread of Islam in Jambi massive. ${ }^{28}$ After that, this religion was even embraced "strongly" by the Malays. They carried out a process called teliti or screening their customs to conform to Islam. The result is a traditional formulation of adat bersendi syarak, syarak bersendi Kitabullah, syarak mengato adat memakai or "adat is based on sharia; what is ordered by sharia, will be used by adat." Although in reality the practiced sharia is not as rigid as in the Quran, the maxim is an affirmation (or claim) of the Malays that their Islam is "total". ${ }^{29}$

The existence of the Muslim community in Jambi, which then grew and became the majority, including until now (see further Table 2), has consequences for the need for Islamic educational institutions. These institutions are useful to ensure the transmission of religious doctrine to the younger generation runs well. Unfortunately, until the beginning of the 20th century, there was no information about these institutions. It could be that at that time "formal" institutions did not yet exist, and the process of transferring Islamic ideas took place simply between individuals or in "unofficial" groups. It is also possible that Jambi residents who want to study Islamic knowledge have to go to other areas, especially the "Islamic centers" in Arabia. This last point is logical because, in 1915 in Chinatown or across the city of Jambi today, several Jambi ulema who were alumni of Mecca formed an organization called Perukunan Tsamaratul Insan. One of the organization's programs is to establish madrasah, which is inspired by the Madrasah Saulatiyah, where most of them studied while in Mecca. The program was successfully realized through the establishment of Madrasah Nurul Iman, Madrasah Nurul Islam, and Madrasah Sa'adatuddaren in 1915-1916 and Madrasah Jawharen in a decade later. ${ }^{30}$

\footnotetext{
28 Elsbeth Locher-Scholten, Kesultanan Sumatra dan Negara Kolonial: Hubungan JambiBatavia (1830-1907) dan Bangkitnya Imperialisme Belanda, trans. by Noor Cholis (Jakarta: KITLV-Jakarta and Banana, 2008), p. 32.

29 M. Husnul Abid, "Kontestasi Kemelayuan: Islam Transnasional, Adat, dan Pencarian Identitas Melayu Jambi”, Mohammad Iqbal Ahnaf (ed.), Praktik Pengelolaan Keragaman di Indonesia: Kontestasi dan Koeksistensi (Yogyakarta: CRCS, 2015), pp. 179-182.

30 Ali Muzakkir, "Transformasi Pendidikan Islam di Jambi: Dari Madrasah ke Pesantren”, Journal of Islamic \& Social Studies, 3, 1 (2017), p. 11.
} 
Table 2. Composition of religious adherents in Jambi, 2019

\begin{tabular}{lc}
\hline Religious Group & Percent \\
\hline Islam & 55.41 \\
Christian & 2.66 \\
Buddhism & 0.97 \\
Catholic & 0.43 \\
Confucianism & 0.05 \\
Hindu & 0.02 \\
Others & 0.01 \\
\hline
\end{tabular}

Source: BPS Provinsi Jambi, "Penduduk Menurut Agama (Jiwa), 2017$2019 " .31$

Meanwhile, a prominent Hadrami scholar, H.M.O. Bafadhal, founded Madrasah al-Khairiyat which had open and tolerant views in 1936. In the same year, in ilir, Banjar migrants who were also alumni of Mecca, founded Madrasah Hidayatul Islamiyah. In ulu or Kerinci, an alumnus of Mecca opened a pengajian since 1920. Later, the forum developed into Madrasah Thawalib Islamiyah al-Rawaniyah and was connected to the Sumatra Thawalib College in Padang Panjang, West Sumatra. ${ }^{32}$

The definition of madrasab in the names of these institutions is, of course, different from the current concept. At that time, madrasab in Jambi was a synonym for pesantren in Java or dayah in Aceh. Led by tuan guru (or kiai for pesantren), they teach kitab kuning to murid (or santri in Java) who come from far away, who are forced to stay in a small, simple hostel they have built around the madrasabs. Later, after the government issued a 1975 decree formalizing madrasah as "public schools" where only 30 percent taught religious material, these madrasabs changed their status to pesantren. Similar characteristics of the two institutions and the influence of Java in Jambi that widened along with the transmigration policy, in addition to the new regulations on education from the Indonesian government, made these changes run smoothly and did not experience significant obstacles.

Although the expansion of public schools has been going on massively since the late 1970s, through the establishment of many schools under Instruksi Presiden (Presidential Instruction, Inpres) program, among others, Jambi's people that were "religious" have not

31 BPS Provinsi Jambi, "Penduduk Menurut Agama (Jiwa), 2017-2019”, https://jambi.bps.go.id/indicator/156/54/1/-penduduk-menurut-agama.html.

32 Muzakkir, “Transformasi Pendidikan Islam”, p. 12. 
forgotten Islamic education. Different from the official government definition, they then developed madrasab as educational institutions that as a whole teach Islamic material, as an alternative to the existing pesantren-style education. This madrasah has very traditional and informal characteristics. While general schools take place in the morning, learning at these madrasabs generally takes place in the afternoon. Some of them do have their own buildings, which are made by the community independently or donated by mosques and nearby areas, while others "borrow" public school buildings that are empty in the afternoon. With only 2-3 hours of study time a day, students usually do not have uniforms and wear sarongs and kopiah (skullcaps). The teachers are local people who are considered to have the capacity for Islamic matters. With these characteristics, they are often referred to as sekolah sore (afternoon schools) or sekolah Arab (Arabic schools).

These madrasabs are actually aimed at "complementing" public schools. Limited religious material in public schools has made Jambi people thirst for Islamic material unsatisfied and a new institution is needed to supply it. Meanwhile, in government-style madrasabs they only get less and less Islamic teachings. Because of this, pupils at madrasabs and public schools are basically the same person. In the morning they go to the public schools, while in the afternoon they go to the madrasabs. Therefore, they get both general lessons and religious lessons which they consider very important.

Although the madrasabs operate informally, the students are still accommodated by the government to take final exams officially. In the exam, they also encountered general subject matters, because government-style madrasabs teach 70 percent of general materials. For traditional madrasabs students, the questions on general subjects are not a problem, because they have learned them in public schools in the morning. With such accommodation, up to the early 2000s, many children in Jambi had two certificates which were equivalent, such as Sekolah Dasar (elementary school, SD) certificate and Madrasah Ibtidaiyah certificate, which were obtained in the same year of graduation.

\section{Standardization of Education and the Decline of Traditional Madrasahs}

In 2003, the Indonesian government issued a new education law, namely Law No. 20 of 2003 concerning the National Education 
System. Some of the crucial articles in the law, among others, state that "the government and local governments guarantee the implementation of minimum compulsory education at the basic education level free of charge", 33 "Compulsory education is the responsibility of the state which is carried out by educational institutions of the government, local governments, and the community", 34 and "The government and local governments are responsible for providing the education budget". 35

The mandate in these articles is then embodied in Bantuan Operasional Sekolah (School Operational Grant, BOS) policy. Intended as budget guarantees for the provision of education provided by the government, BOS is given to both public schools and madrasabs, namely SD/MI, SMP/MTs, and SMA/MA. In addition to each school being required to register or be registered, another requirement that must be met in order to receive BOS is that schools or madrasabs must qualify what are known as national education standards or "minimum criteria for the education system" applied in Indonesia. The education standardization policy, which is also mandated by Law 20/2003, includes eight standards: content, process, competence of graduates, education personnel, facilities and infrastructure, management, financing, and assessment. ${ }^{36}$ Schools or madrasabs that meet these eight standards can receive BOS, while those that do not qualify are not entitled to receive BOS.

With lessons held in the afternoons, which last only 2-3 hours a day, it is difficult for traditional madrasahs to meet these standards. Regarding content standards, for example, Regulation of Minister of Education and Culture No. 22 of 2006 states that the number of learning hours per week for students in grades 1-3 of SD/MI is 26-28 learning hours (one lesson hour lasts 35 minutes) and for grade 4-6 students is 32 hours lessons, outside of recess. ${ }^{37}$ If learning in a school/madrasah lasts six days a week, it will take at least three hours each day to meet these standards. The impossibility for traditional

\footnotetext{
33 Article 34 (2) Law 20 of 2003.

34 Article 34 (3) Law 20 of 2003.

35 Article 44 (2) Law 20 of 2003.

36 Article 35 (1) Law 20 of 2003.

37 Regulation of Minister of Education and Culture No. 22 of 2006 concerning Content Standards for Primary and Secondary Education, especially Chapter 3 on Learning Loads.
} 
madrasabs to qualify content standards if their education is held in the afternoon, is followed by a policy of the Ministry of Religion which requires madrasabs to be held in the morning. Those who still insist on holding later in the evening are not allowed to bear the name madrasah, but must change to diniyah takmiliyah. 38

The regulations concerning diniyah takmiliyah include Peraturan Pemerintah Nomor 55 Tabun 2007 tentang Pendidikan Agama dan Pendidikan Keagamaan (Government Regulation No. 55 of 2007 concerning Religious Education). The regulation states that diniyah takmiliyah is an Islamic religious education that is on a non-formal basis. Similar to pengajian, majelis taklim, and pendidikan Alquran, diniyah takmiliyah can be held with grades or not. Learning in this institution is actually not independent, because it aims "to complement the education (lessons?) of the Islamic religion" obtained in public schools or madrasabs, "in the context of increasing the faith and piety of students." 39

When the education standardization policy was implemented in madrasabs in Jambi, about 70 percent of the 2,282 registered madrasabs did not meet the standards. As shown in the Table 3, the percentage of the number of MIs that do not qualify has almost reached 90 percent and in the next two levels the percentage has decreased. The explanation is that since the beginning the MI level was indeed the most informal and held in the afternoon (students who study double with schools in the morning are the most at this level), while the number of MTs and MA that conduct education in the afternoon is less because their learning load is more a lot so that it is difficult for students to attend multiple schools. The licenses for madrasabs that did not meet these standards were then revoked by the Ministry of Religion. ${ }^{40}$ Their status of MI, MTs, and MA then changed to,

38 Decree of Head of Jambi Regional Office of Ministry of Religion No. Kw.05.4/4/PP.00.4/253/2008 concerning Institutional Status Control and Administration of Private Madrasah Ibtidaiyah in Jambi Province; Decree of Head of Jambi Regional Office of Ministry of Religion No. Kw.05.5/7/HK.00.5/532/2008 concerning Technical Guidelines for the Establishment and Implementation of Diniyah Takmiliyah.

39 See further Government Regulation No. 55 of 2007 concerning Religious Education, especially Chapter 1 Islamic Educations.

40 Decree of Head of Jambi Regional Office of Ministry of Religion No. Kw.05.4/4/PP.00.4/3697/2008 concerning Revocation of Permit for Private Madrasah Ibtidaiyah. 
respectively, diniyah takmiliyah awaliyah, diniyah takmiliyah tsaniyah, and diniyah takmiliyah aliyah.

Table 3. The Implementation of Madrasah Standardization Policies in Jambi Province, 2008

\begin{tabular}{lrrrr}
\hline \multicolumn{1}{c}{ Level } & Total & Standardized & Unstandardized & Percentage \\
\hline MI & 1.774 & 223 & 1.551 & 87,42 \\
MTs & 346 & 309 & 37 & 10,69 \\
MA & 162 & 157 & 5 & 3,08 \\
Total & 2.282 & 689 & 1.593 & 69,80 \\
\hline
\end{tabular}

The change from non-standard madrasahs to diniyah takmiliyahs has resulted in the deterioration of these traditional Islamic education institutions. Subsequent periods then saw the interest of the people for the institutions in decreasing and some of them were forced to stop operating or close, especially those in urban areas. There are of course many factors that cause this phenomenon. In addition to their status which is considered to be "declining" and merely "complementary" (takmiliyah) compared to before the change, "discrimination" in terms of funding, namely diniyah takmiliyah not receiving BOS, also makes it difficult for them to compete in the midst of a massive government campaign, which of course affects public perception, that education should be free after Law Number 20 of 2003. Regarding the funding, the Ministry of Religion has provided a block grant to assist diniyah takmiliyah. However, the number of diniyah takmiliyah that can be accommodated by this funding scheme is very small, namely in Jambi Province only 40 in 2008 and 47 in the following year. Another weakness is the funding that is not continuous. If a diniyah takmiliyah has received it in a year, the next year the block grant is rotated or given to another diniyah takmiliyah.

Realizing that diniyah takmiliyah generally do not receive funding from the central government, several local governments in Jambi provide assistance mainly through grant schemes. The Batanghari Regency, for example, in 2017 provided School Operational Funds (Dana Operasional Sekolah, DOS) which included the cost of purchasing books or books, office stationery, electricity and water payments, light renovation of buildings, light table and chair rehabilitation, official travel, and food expenses. In addition, to provide additional income for diniyah takmiliyah teachers, the Batanghari Regency provides an additional monthly salary called welfare 
assistance. ${ }^{41}$ However, the nature of such grants was not permanent and not continuous, and the magnitude varied between regions. The absence of regulations that compel regional heads to budget a certain amount for diniyah takmiliyah makes such assistance highly dependent on the awareness of regional heads and their generosity. In some areas, assistance may even be non-existent or lacking, which makes teachers often complain about it in public spaces or in the media in Jambi. ${ }^{42}$

Another important factor contributing to the decline of diniyab takmiliyab is the busyness of school and madrasab students, who learn in the morning, to prepare themselves in a tightened assessment system, as part of the standardization policy for assessment and standardization of graduate competencies. Class hours were then supplemented by tutoring given by their teachers in the afternoons, in addition to many of them taking additional courses at tutoring institutions which were becoming increasingly popular. Growing up in a competitive climate for high marks, students lose free time which allows them to get additional education at diniyah takmiliyah in the afternoons. These educational institutions then lost interest and many of them were forced to close, especially in cities. In Jambi City, for example, the number of diniyah takmiliyah in 2009 or after conversion as a result of the standardization policy was 112.This number has decreased to 105 in 2015 and continues to fall in 2018 and 2020 to, respectively, 86 and 72.43

The question is, where and how do the people of Jambi who claim to be "religious", which is reflected in the traditional maxim they hold, resolve their thirst regarding Islamic education for their children? The presence of new educational institutions, which continue to use the secular school system but add striking Islamic material and make it a strong distinction, such as integrated Islamic schools, then gets its context and relevance in Jambi, as will be further elaborated on below.

\footnotetext{
${ }^{41}$ Batanghari Regent Regulation No. 14 of 2017 concerning School Operational Funds and Welfare for Diniyah Takmiliyah Awaliyah in Batanghari Regency.

42 "Dewan Minta Pemkab Siapkan Anggaran untuk DTA", https://www.jambiindependent.co.id/read/2020/03/03/48233/dewan-minta-pemkab-siapkan-anggaranuntuk-dta.

43 The figures are compiled from PAPKIS (Pendidikan Agama dan Keagamaan Islam) and SIPAKIS (Sistem Informasi Pendidikan Agama dan Keagamaan Islam) directories provided by Jambi Regional Office of Ministry of Religion. These directories are available online in www.papkis.id and www.sipakis.kmng.id.
} 


\section{The Rise of Integrated Islamic Schools}

The decline of traditional madrasabs in Jambi has opened up opportunities for the entry and development of new educational institutions such as integrated Islamic schools. The ability of Tarbiyah Movement activists in establishing and managing their educational institutions, in addition to connections with local political leaders and actors, is an important resource that contributes to the development of integrated Islamic schools. On many occasions, they often voiced the importance of an educational vision and Islamic values that were carried by their schools, which made the Jambi community thirst for Islamic teaching to get an antidote.

The emergence and development of integrated Islamic schools cannot be separated from the development of national education system and the emergence of the Tarbiyah Movement in Indonesia. The establishment of integrated Islamic schools is the Islamist group's response to the dualism in the education system that separates general education and religion, which they call a secular system. The discourse of secularization or separation between religion and politics surfaced in the 1970s and became a hot topic of debate among Indonesian Islamic intellectuals. Some accepted this separation as a consequence of the form of the state which was originally built not based on a particular religion, while some others rejected and considered the discourse as being influenced by liberal Western ideas. Recently, the implementation of Pancasila as the single principle by the New Order in the 1980s was seen as evidence of the tendency of secularization by some Muslims. ${ }^{44}$ As an Islamist organization that bases its ideology primarily on the thoughts of Hasan al-Banna, the Tarbiyah Movement rejects such separation and argues that Islam is al-din or a way of life that is comprehensive, total, and encompasses all aspects of life. ${ }^{45}$ The integrated Islamic schools that they founded then assumed the task of teaching Islam as a comprehensive and integral unit, or syumühyya, as a resistance to secular, dichotomous, juz'ty $y$ anderstanding. ${ }^{46}$

\footnotetext{
44 Karel A. Steenbrink, "Towards a Pancasila Society: The Indonesian Debate on Secularization, Liberalization and Development 1969-1989", Exchange, 54 (1989), pp. $1-28$.

45 Muhtadi, Dilema PKS, p. 41.

46 Jaringan Sekolah Islam Terpadu, Standar Mutu Sekolah Islam Terpadu (Jakarta: Jaringan Sekolah Islam Terpadu, n.d.), p. 35.
} 
The first integrated Islamic school in Indonesia is Salman al-Farisi in Bandung, which has served the level of early child education since 1989 and elementary school since 1991. Founded by the city's Tarbiyah Movement activists, Salman al-Farisi clearly takes its name from the Salman Mosque at the Institut Teknologi Bandung, which has been the center of their activism. After that, in cities where the movement had grown, similar schools were also established, for example Nurul Ilmi in Depok, al-Hikmah and al-Khayrot in Jakarta, Ummul Quro in Bogor, and Iqro in Bekasi. ${ }^{47}$ The establishment of the schools became possible in the last decades of the New Order after the regime began to draw closer to Islamic groups. During this period, Ikatan Cendekiawan Muslim Indonesia (Indonesian Muslim Intellectuals Association, ICMI) was given the blessing to be founded, with its chairman B.J. Habibie, Minister of Research and Technology who is known to be close to Suharto. Influenced by the minister, the New Order then introduced the idealized vision of Indonesian people, namely those who master science and technology and have faith and piety, often abbreviated as Iptek and Imtak.48 This vision has led several Muslim figures and groups, including the Tarbiyah Movement, to look for role models of educational institutions that are able to make it happen, which combines Islamic science on the one hand and general knowledge on the other in a balanced manner. The integrated Islamic school is one of the results of this endeavor, which later found great opportunities for widespread development after the fall of the New Order in 1998 and liberal policies were implemented. In this new era, the Tarbiyah Movement is at the forefront of this effort and their integrated Islamic schools are among the most developed. Until 2017, there were at least 2,700 integrated Islamic school units in Indonesia. ${ }^{49}$ Under JSIT as the umbrella organization, these schools expanded not only in cities in Java, but also in other regions of Indonesia.

The presence of the integrated Islamic schools in Jambi is part of the massive expansion of these schools in Indonesia by the Tarbiyah Movement, which was brought and founded by their local exponents.

\footnotetext{
47 "10 Tahun JSIT Indonesia Bangun Pendidikan Lewat SIT", Republika, January 31, 2014.

48 Sulfikar Amir, "Symbolic Power in a Technocratic Regime: The Reign of B.J. Habibie in New Order Indonesia", Sojourn: Journal of Social Issues in Southeast Asia, 22, 1, (2007), pp. 83-106.

${ }^{49}$ Asyari, "Incorporating Islamism", pp. 29-58.
} 
In Jambi, the early activists of the movement were mostly students of Universitas Jambi, the public university with the largest number of students and departments in Jambi Province. Although information on its first appearance on the campus is difficult to ascertain, by the 1980s the movement had taken root among students. Using the campus mosque, Masjid Al-Rahman, as a center for activism, they later made the name of the mosque a student activity unit (UKM) which they founded in 1991.50 There, this movement forged its exponents in usrabs, a closed cell system of recruiting and training cadres a la Tarbiyah, which produced organizational skills and solidity among them. ${ }^{51}$ This movement grew stronger and its activists then also entered and controlled other organizations such as the executive body and the student senate. After graduating, some of them became lecturers at the campus, which further cemented the movement at Universitas Jambi, while others became politicians through PKS. Apart from them, alumni from campuses outside Jambi, where they knew and became members of the Tarbiyah Movement, also helped raise the movement upon their return to Jambi after finishing their studies. ${ }^{52}$ Through their networks, the integrated Islamic schools in Jambi were then established.

The first integrated Islamic school in Jambi is Nurul Ilmi, under the Nurul 'Ilmi Foundation which was founded in 2001, and is not far from the administrative center of Jambi Province. From this school, other integrated Islamic schools were also born such as al-Shiddiqi, alNahl Percikan Iman, Insan Madani, Mutiara Hati, and Al-Azka. Serving education levels from early childhood to senior high school, in general what is called a combination of Islamic science and general science in integrated Islamic schools is actually a mix of two curricula. First, the curriculum of the school system in general, compiled by the Ministry of Education and Culture. Second, the curriculum established by JSIT, which contains Islamic materials such as reading and writing and memorizing the Quran, Hadith, fiqh, theology, worship practices and history of the prophet, as well as Arabic language. In addition to the two curricula, there are student self-development programs, including extracurricular activities such as scouting, sports and arts,

50 "Profil UKM Rohis Ar-Rahman Unja", http://ldkarrahman.or.id/2016/10/06/profil-ukm-rohis-ar-rahman-unja/.

51 Samsu and Abid, "Organizing People".

52 Abid, "Kontestasi Kemelayuan”, pp. 194-195. 
tahfiz, graduations, faith and piety building nights or MABIT (malam bina iman dan takwa), and excursions. ${ }^{53}$ The combined curriculum is intended to form Islamic individuals who are the goals of an integrated Islamic school, namely individuals who have characters as idealized by Hasan al-Banna: have a strong physique, good morals, broad insight, creative and skilled at work, strong faith, righteous ideology, diligent worship, stable emotion, discipline, able to implement Islamic values, and benefit others. ${ }^{54}$

There is no doubt that the networks between the members of the Tarbiyah Movement and their inseparable roles between being ustä/ah (or murabbi/yah in usrah), teachers, and even political cadres in PKS also contribute to the development of integrated Islamic schools. Some of the senior teachers and administrators of the foundations that oversee these schools are local politicians in PKS. A small proportion of them were even elected to be regional heads, while far more were members of regional councils. To name a few, Henri Masyhur, Syafrudin Dwi Apriyanto, and Heru Kustanto are former teachers at Nurul 'Ilmi who once served as chairman of the PKS branch of Jambi Province. Syafrudin is even now the deputy regent of Bungo. Jasrul, a Jambi City councilor from PKS, is the chairman of the Nurul 'Ilmi Foundation. Meanwhile, Antiyosefa, head of al-Shiddiqi, was several times elected to the council of the PKS. As politicians, their actions cannot be separated from the interests of their integrated Islamic schools. For example, since 2007 a local bureaucrat has donated land and buildings for an integrated Islamic school in Jambi. The connection continued when the bureaucrat ran for regional head elections in 2013 and 2018, the party belongs to the Tarbiyah Movement, PKS, was one of its main supporters. Such support practices in local political contestation can also lead to grants from local governments (whose regional heads they support and win) to foundations under the Tarbiyah Movement, including those that oversee integrated Islamic schools.

\footnotetext{
${ }^{53}$ Jaringan Sekolah Islam Terpadu, Standar Mutu, pp. 151-153.

54 The sentences and sequences used by each schools may be different, even though the objectives are primarily the same. About the goals, compare to al-Banna's idea as cited by Ali Abdul Halim Mahmud, Ikhwanul Muslimin: Konsep Gerakan Terpadu, Vol. 2, transl. Masykur Halim and Ubaidillah (Jakarta: Gema Insani Press, 1997), pp. 16-17.
} 
Although known as expensive schools, ${ }^{55}$ in fact integrated Islamic schools in Jambi have received good acceptance from the people. In each admission, the number of applicants for these schools exceeds the quota they can accommodate. There are at least two explanations. First, the religious character of the Jambi Malays, which is reflected in the maxim they adhere to, adat bersendi syarak, syarak bersendi kitabullah, requires educational institutions that teach religion. As has been stated, in the past this need was met initially by the presence of traditional madrasabs, which served religious education in the afternoons, after which the children received general subjects at school in the morning. The decline of these madrasabs after the education standardization policy in 2008 made the need for new Islamic education institutions inevitable. Integrated Islamic schools then answer this need by offering a schooling system combined with Islamic education.

Second, the transition from traditional madrasabs to integrated Islamic schools was also marked by a change in society from agrarian to urban which in turn demanded their attendance at work for eight hours a day. Losing most of their time in surveillance raises concerns for the child's safety and their fear of engaging in juvenile delinquency and drug addiction. This moral panic has made Jambi's middle-class urban Muslims - whose numbers have increased since the distribution of state revenues between the central and regional regions after regional autonomy, which resulted in an increase in Jambi's economy compared to the national average ${ }^{56}$ - chose to entrust their children to integrated Islamic schools that offer a full day school system. Even though they pay much more than public schools, they do not mind because it is considered commensurate with the "quality" and services their children get at school, in addition to fulfilling their thirst for religious education.

Meanwhile, the role of integrated Islamic school promotions is also important to highlight. These promotions not only reach exponents of

\footnotetext{
55 BOS policy prohibits public schools owned by the state from charging fees, while initial tuition fee in an integrated Islamic school at least Rp. 10 million and monthly fee Rp. 750,000 in 2020.

${ }^{56}$ Except for 2003, Jambi's economic growth rate was always higher than the national average. In the last few years, Jambi is even the highest in Sumatra. It is resulted from domestic and foreign investment, especially in the fields of plantations and forest products. See M. Husnul Abid, "Perkembangan Industri Koran Lokal di Jambi PascaOrde Baru, 1998-2015: Analisis Ekonomi-Politik", Unpublished M.A. thesis, Universitas Gadjah Mada, Yogyakarta (2016), pp. 78-81.
} 
the Tarbiyah Movement, the most potential group that will enroll their children in these schools, but also to the wider public. For exponents of the movement, getting their children to an integrated Islamic school was almost a necessity. These schools are the most important educational means ensuring the transmission of Islamist ideas to their children. The presence of integrated Islamic schools, at least at their inception, were intended to meet the educational needs of children from the Tarbiyab families, whose existence became increasingly urgent as the group grew after the Reformasi.

Apart from being designated for their exponents, the integrated Islamic school has also become a medium of preaching for the Tarbiyah Movement to the wider public and, therefore, promotion to them is important. On the streets of Jambi City, billboards informing the existence of integrated Islamic schools and their registration to the public appear dominant over the billboards belong to other schools. Some of these billboards show the achievements of integrated Islamic school students in many competitions both local and national levels, some of which are actually inter-school competitions organized by JSIT. Integrated Islamic school stickers are also installed and can be easily seen or found on the windows of the cars belonging to the students' parents. The promotion from these parents has a significant role too. In offices, these parents often proudly tell of their children having memorized 1-2 chapters of the Quran, one of the skills emphasized and taught by integrated Islamic schools. They often share photos or videos of their children graduating each time they complete a chapter of memorization on their social media channels. The show of their children reciting the Quran without text during their graduations, ending with the emotional embrace of their parents on stage and the child's special request to be allowed to continue memorizing up to 30 chapters for "wanting to take their parents to heaven", improves the dramatic effect of the graduations. Proving that the integrated Islamic schools have educated their children with Islamic material well, these promotions have succeeded in attracting the Jambi people to enroll their children there.

\section{Conclusion}

This article has demonstrated that apart from developments and political policies at the national level, the local context also needs to be considered in order to investigate the new institutions of Islamic 
education in Indonesia. From a social movement perspective, the fall of the New Order in 1998 followed by liberal policies became a political opportunity structure that made the Tarbiyah Movement formalized its movement and develop rapidly. In addition to creating political parties and many other organizations, the movement also established schools that combined both the Ministry of Education and Culture curriculum as well as their own Islamic curriculum. Under Integrated Islamic School Network as an umbrella organization, these schools have developed rapidly, especially in urban areas in Indonesia.

In the Jambi context, the development of integrated Islamic schools was also influenced by the decline of traditional madrasabs after the education standardization policy in 2008. In the past, the traditional madrasabs were considered as places for religious Jambi people to educate their children regarding Islamic materials. Madrasabs that offer learning in the afternoon complement the public schools that teach their students in the morning. When the standardization policy was implemented, the majority of the madrasabs did not meet the minimum criteria for an educational institution and after that their licenses were revoked and their status had to change to diniyah takmiliyah. The change in status and discrimination in funding has made traditional madrasabs degenerate and have lost interest. It was there that the integrated Islamic schools took over the role that was played by traditional madrasabs. Growing up especially in urban areas at the right time, the integrated Islamic schools soon became the new destination for the Jambi Malay people to send their children to school.

There is no doubt that the networks between members of the Tarbiyah Movement, both directly and indirectly involved, and their ability to succeed the group's Islamist agendas, played a major role in the rapid development of the integrated Islamic schools. Most of them are trained and skilled in organizations, especially thanks to the mentoring process and long training in usrah, the cell system in the training of Tarbiyah cadres. Their ability becomes very useful and practical to be applied in many areas of life, including when they manage the integrated Islamic schools. Their roles that are not separated between being ustaz/ah, teachers, even politicians, in addition to their political networks through PKS, make it easier for them to establish and raise donations for the construction of integrated Islamic schools. They are also skilled in framing the issue of the importance of 
Islamic education that they carry in the integrated Islamic schools and are very enthusiastic in promoting them. The promotions were then greeted by the parents of the students, who echoed them to many people, making the new institutions even more popular among the Muslim community in Jambi. []

\section{References}

"10 Tahun JSIT Indonesia Bangun Pendidikan Lewat SIT." Republika. January 31, 2014.

"Dewan Minta Pemkab Siapkan Anggaran untuk DTA." https://www.jambi-independent.co.id/read/2020/03/03/48233/dewan-minta-pemkab-siapkan-anggaran-untuk-dta.

"Profil UKM Rohis Ar-Rahman Unja." http://ldkarrahman.or.id/2016/10/06/profil-ukm-rohis-ar-rahman-unja/.

Abdullah, Taufik. Schools and Politics: The Kaum Muda Movement in West Sumatra (1927-1933). Ithaca: Southeast Asia Program, Cornell University, 1971.

Abid, M. Husnul. "Kontestasi Kemelayuan: Islam Transnasional, Adat, dan Pencarian Identitas Melayu Jambi." Mohammad Iqbal Ahnaf (ed.), Praktik Pengelolaan Keragaman di Indonesia: Kontestasi dan Koeksistensi. Yogyakarta: CRCS, 2015.

--------. "Perkembangan Industri Koran Lokal di Jambi Pasca-Orde Baru, 1998-2015: Analisis Ekonomi-Politik.” Unpublished M.A. thesis, Universitas Gadjah Mada Yogyakarta, 2016.

Amir, Sulfikar. "Symbolic Power in a Technocratic Regime: The Reign of B.J. Habibie in New Order Indonesia." Sojourn: Journal of Social Issues in Southeast Asia 22, 1 (2007).

Ananta, Aris, et.al. Demography of Indonesia's Ethnicity. Singapura: ISEAS, 2015.

Andaya, Barbara Watson. "Upstreams and Downstreams in Early Modern Sumatra." The Historian 53, 3 (1995).

Asyari, Suaidi. "Incorporating Islamism into Secular Education System: An Attempt of Gradual Islamization of the State and Society by 
an Indonesian Tarbiyah Movement in Jambi." Journal of Indonesian Islam 11, 1 (2017).

Batanghari Regent Regulation No. 14 of 2017 concerning School Operational Funds and Welfare for Diniyah Takmiliyah Awaliyah in Batanghari Regency.

BPS Provinsi Jambi. "Penduduk Menurut Agama (Jiwa), 2017-2019." BPS Provinsi Jambi, December 16 ${ }^{\text {th }}$, 2020, https://jambi.bps.go.id/indicator/156/54/1/-penduduk-menurut-agama.html.

Bryner, Karen. "Piety Projects: Islamic Schools for Indonesia's Urban Middle Class". Unpublished Ph.D thesis, Columbia University, 2013.

Damanik, Ali Said. Fenomena Partai Keadilan: Transformasi 20 Tabun Gerakan Tarbiyah di Indonesia. Jakarta: Teraju, 2002.

Daya, Burhanuddin. Gerakan Pembaharuan Pemikiran Islam: Kasus Sumatera Thawalib. Yogyakarta: Tiara Wacana, 1990.

Decree of Head of Jambi Regional Office of Ministry of Religion No. Kw.05.4/4/PP.00.4/253/2008 concerning Institutional Status Control and Administration of Private Madrasah Ibtidaiyah in Jambi Province.

Decree of Head of Jambi Regional Office of Ministry of Religion No. Kw.05.5/7/HK.00.5/532/2008 concerning Technical Guidelines for the Establishment and Implementation of Diniyah Takmiliyah.

Decree of Head of Jambi Regional Office of Ministry of Religion No. Kw.05.4/4/PP.00.4/3697/2008 concerning Revocation of Permit for Private Madrasah Ibtidaiyah.

Dhofier, Zamakhsyari. Tradisi Pesantren: Studi tentang Pandangan Hidup Kyai. Jakarta: LP3ES, 1982.

Furqon, Aay Muhammad. Partai Keadilan Sejabtera: Ideologis dan Praksis Politik. Kaum Muda Muslim Indonesia Kontemporer. Jakarta: Teraju, 2004.

Gamson, William A. "Constructing Social Protest". Hank Johnston and Bert Klandermans (eds), Social Movements, Protest, and 
Contention, vol. 4. Minneapolis: The University of Minnesota Press, 1995.

Government Regulation No. 55 of 2007 concerning Religious Education.

Hasan, Noorhaidi. "Education, Young Islamists and Integrated Islamic Schools in Indonesia." Studia Islamika 19, 1 (2012).

-. "Islamizing Formal Education: Integrated Islamic School and a New Trend in Formal Education Istitution in Indonesia." RSIS Working Paper, No. 172. Singapore: Nanyang Technological University, 2009.

-. Laskar Jihad: Islam, Militansi, dan Pencarian Identitas di Indonesia Pasca-Orde Baru, trans. by Hairus Salim. Jakarta: LP3ES, 2008.

Hefner, Robert W. "Islamic Schools, Social Movements, and Democracy in Indonesia". Robert W. Hefner (ed.), Making Modern Muslims: The Politics of Islamic Education in Southeast Asia. Honolulu: University of Hawai'i Press, 2009.

Hwang, Julie Chernov. Peaceful Islamist Mobilization in the Muslim World: What Went Right. New York: Palgrave Macmillan, 2009.

Jaringan Sekolah Islam Terpadu, Standar Mutu Sekolah Islam Terpadu. Jakarta: Jaringan Sekolah Islam Terpadu, n.d.

Kadir, Suzaina. "Emerging Trends in Islamic Education in Indonesia." Paper presented at the 3rd Redesigning Pedagogy International Conference, National Institute of Education, Singapore, 1-3 June 2009.

Kozok, Uli. Kitab Undang-undang Tanjung Tanab: Naskah Melayu yang Tertua. Jakarta: Yayasan Obor Indonesia, 2006.

Law No. 20 of 2003 concerning the National Education System.

Locher-Scholten, Elsbeth. Kesultanan Sumatra dan Negara Kolonial: Hubungan Jambi-Batavia (1830-1907) dan Bangkitnya Imperialisme Belanda, trans. by Noor Cholis. Jakarta: KITLV-Jakarta and Banana, 2008.

Mahmud, Ali Abdul Halim. Ikhwanul Muslimin: Konsep Gerakan Terpadu, Vol. 2, transl. by Masykur Halim and Ubaidillah. Jakarta: Gema Insani Press, 1997. 
Muhtadi, Burhanuddin. Dilema PKS: Suara dan Syariah. Jakarta: Kepustakaan Populer Gramedia, 2012.

Muzakkir, Ali. "Transformasi Pendidikan Islam di Jambi: Dari Madrasah ke Pesantren." Journal of Islamic \& Social Studies 3, 1 (2017).

Porta, Donatella Della, and Mario Diani. Social Movements: An Introduction. Madison-Oxford-Victoria: Blackwell, second edition 2006.

Rahmat, M. Imdadun. Ideologi Politik PKS: Dari Masjid Kampus ke Gedung Parlemen. Yogyakarta: LKiS, 2008.

Regulation of Minister of Education and Culture No. 22 of 2006 concerning Content Standards for Primary and Secondary Education, especially Chapter 3 on Learning Loads.

Samsu, and M Husnul Abid. "Organizing People, Islamizing the Society: Organizations, Da'wah, and Ideology within the Indonesian Tarbiyah Movement." forthcoming.

Sirozi, Muhammad. Politik Kebijakan Pendidikan di Indonesia: Peran Tokobtokoh Islam dalam Penyusunan UU No. 2/1989. Leiden-Jakarta: INIS, 2004.

Steenbrink, Karel A. “Towards a Pancasila Society: The Indonesian Debate on Secularization, Liberalization and Development 1969-1989." Exchange 54 (1989).

--------. Pesantren, Madrasah, Sekolah: Pendidikan Islam dalam Kurun Moderen. Jakarta: LP3ES, 1994.

UNESCO. "Muarajambi Temple Compound." https://whc.unesco.org/en/tentativelists/5465/.

van Bruinessen, Martin. Kitab Kuning, Pesantren dan Tarekat: Tradisi-tradisi Islam di Indonesia. Bandung: Mizan, 1995. 
Marwazi and M. Husnul Abid

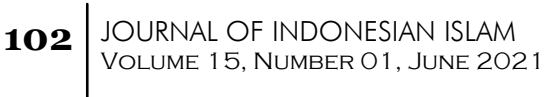

